JPPUMA: Jurnal Ilmu Pemerintahan dan Sosial Politik UMA (Journal of Governance and Political Social UMA),

6 (2) (2018): 112-119, DOI: 10.31289/jppuma.v6i2.1622

JPPUMA: Jurnal Ilmu Pemerintahan dan Sosial Politik UMA

(Journal of Governance and Political Social UMA)

Available online http://ojs.uma.ac.id/index.php/jppuma

\title{
Mendorong Transparansi dan Akuntabilitas Dana Kampanye pada Penyelenggaraan Pilkada Serentak Tahun 2018
}

\section{Encouraging Transparency and Accountability of Campaign Funds on the Implementation of Simultaneous Local Elections in 2018}

\author{
Hermansyah Putra \\ Program Studi Ilmu Politik, Fakultas Ilmu Sosial dan Ilmu Politik \\ Universitas Padjajaran, Indonesia
}

Diterima Juni 2018; Disetujui Desember 2018; Dipublikasikan Desember 2018

\begin{abstract}
Abstrak
Begitu pentingnya peran kampanye untuk dapat menarik dan meyakinkan pemilih, dimana semakin massif dan intesif kampanye yang di lakukan maka semakin besar pula dana kampanye yang di butuhkan. Dengan pendanaan yang besar maka peserta pemilu mempunyai kesempatan yang lebih besar untuk lebih menyakinkan pemilih. Ketika kampanye membutuhkan dana yang besar, yang akan menjadi persoalan adalah keabsahan atas sumber dana yang di kumpulkan, untuk itu perlu adanya aturan yang dapat mengatasi persoalan tersebut. Untuk itu Komisi Pemilihan Umum (KPU) telah membuat aturan hukum untuk memastikan dana kampanye yang di gunakan peserta pemilu berasal dari sumber-sumber yang sah. Pengaturan dana kampanye di mulai dengan pembuatan rekening khusus dana kampanye, pengaturan sumber pendanaan dan pembatasan jumlah sumbangan. Dana kampanye tersebut wajib di serahkan kepada Komisi pemilihan umum sebagai bentuk pertanggungjawaban melalui laporan dana kampanye. Laporan dana kampanye ini kemudian di audit oleh Kantor Akuntan Publik (KAP) yang di tunjuk secara resmi oleh KPU untuk memastikan laporan yang di serahkan memenuhi aspek kepatuhan atau tidak. Adapun sanksi administrasi di berikan atas setiap pelanggaran terkait penggunaan dan pelaporan dana kampanye. Dengan serangkaian aturan di atas di harapkan dapat mendorong transparansi dan akuntabilitas laporan dana kampanye peserta pemilu.
\end{abstract}

Kata Kunci: Transparansi, Akuntabilitas, Pengaturan, Dana Kampanye

\begin{abstract}
So important is the role of the campaign to be able to attract and convince voters, where the more massive and intensified campaigns are carried out, the greater the campaign funds needed. With large funding, election participants have a greater opportunity to convince voters. When the campaign requires large funds, what will be a problem is the legitimacy of the sources of funds collected, for which there is a need for rules that can overcome the problem. For this reason, the General Election Commission (KPU) has made legal regulations to ensure that campaign funds used by election participants come from legitimate sources. Campaign funding arrangements start with the creation of special accounts for campaign funds, arrangement of funding sources and restrictions on the number of donations. Campaign funds must be submitted to the Election Commission as a form of accountability through campaign finance reports. This campaign fund report was then audited by the Public Accountant Office (KAP) which was formally appointed by the KPU to ensure that the reports submitted fulfilled the compliance aspects or not. The administrative sanctions are given for each violation related to the use and reporting of campaign funds. With a series of rules above, it is expected to be able to encourage transparency and accountability of election fund campaign campaign reports.
\end{abstract}

Keywords: Transparency, Accountability, Rules, Campaign Funds.

How to Cite: Putra, H. (2018). Mendorong Transparansi dan Akuntabilitas Dana Kampanye pada Penyelenggaraan Pilkada Serentak Tahun 2018. JPPUMA: Jurnal Ilmu Pemerintahan dan Sosial Politik UMA (Journal of Governance and Political Social UMA), 6 (2): 112-121.

*Corresponding author:
E-mail: herman.filgi@gmail.com ISSN 2549-1660 (Print) ISSN 2550-1305 (Online) 
JPPUMA: Jurnal Ilmu Pemerintahan dan Sosial Politik UMA (Journal of Governance and Political Social UMA), 6 (2) (2018): 112-121.

\section{PENDAHULUAN}

Pemilu merupakan ciri dari demokrasi, dimana pemilu merupakan bentuk kedaulatan rakyat dimana rakyat secara bebas dapat memilih wakilnya untuk duduk dalam pemerintahan. Dalam sistem demokrasi, Partai Politik (Parpol) menjadi bagian yang tak terpisahkan, dimana Parpol menjadi wadah dalam menjaring calon yang mempunyai kapasitas untuk memimpin. Adapun tujuan di laksanakannya pemilu di antaranya adalah: pertama, terpilihnya para wakil rakyat dan pemimpin yang tidak hanya representatif, tetapi juga bertanggung jawab; kedua, terbentuknya pemerintah yang bisa memerintah (governable); ketiga, menghasilkan pemerintahan yang kuat dan demokratis karena memperoleh legitimasi rakyat; keempat, terbitnya kebijakan publik berdasarkan kepentingan rakyat dan negara.

Dalam Menjalankan tugas dan fungsinya, KPU mempunyai kewajiban untuk melaksanakan seluruh proses dari tahapan Pemilu. Adapun teknis setiap tahapan tersebut diatur tersendiri dalam PKPU (Peraturan KPU) dan Kep. KPU (Keputusan KPU) dalam hal petunjuk teknis secara spesifik. Proses Pemilu atau Pilkada dimulai dari tahapan Persiapan, Pelaksanaan dan evaluasi. Salah satu proses yang dilakukan dalam tahap pelaksanaan pemilu adalah tahapan laporan dan audit dana kampanye.

Bagi peserta pemilu, kampanye menjadi sarana untuk menarik dan meyakinkan pemilih; sedangkan bagi pemilih, kampanye merupakan wadah untuk mengenal lebih dalam terhadap peserta pemily yang pantas di pilih. Untuk dapat melakukan kampanye tentunya membutuhkan banyak dana, semakin massif dan intensif kampanye yang di lakukan, maka akan semakin besar dana yang di butuhkan. (Supriyanto, 2015). Dengan kemampuan pendanaan yang besar, peserta pemilu mempunyai kesempatan lebih banyak dalam meyakinkan pemilih sehingga peluang mendapatkan suara semakin besar.

Peraturan telah mengatur bagaimana pendanaan Parpol dan pendanaan kampanye untuk memastikan transparansi dan menjaga independensi Parpol atau peserta terpilih dari dampak uang yang di keluarkan oleh para donatur. Pengaturan pendanaan kampanye sendiri tidak dimaksudkan untuk melarang Parpol dan kandidat menerima donasi akan tetapi mengatur keabsahan sumber dana sehingga Parpol dan kandidat masih memiliki fleksibilitas untuk mengumpulkan dana kampanye dan tetap dapat mempertahankan kemandiriannya untuk memperjuangkan kepentingan rakyat. (Supriyanto, 2013).

Penelitian terdahulu yang di lakukan oleh (Anjalline, Anggraini, \& Indrayati, 2014) ditinjau dari aspek hukum dengan metode penelitian yuridis normatif (legal research), dengan judul "Pengaturan Dana Kampanye Pemilihan Umum Sebagai Tanggung Jawab Calon Anggota Legislatif Berdasarkan Undang Undang Nomor 8 Tahun 2012 Tentang Pemilihan Umum Anggota Dewan Perwakilan Rakyat, Dewan Perwakilan Daerah, Dan Dewan Perwakilan Rakyat Daerah" memberikan dua kesimpulan yaitu: (1) Pengaturan dana kampanye berdasarkan UU No 8 Tahun 2012 tidak cukup baik dan seakanakan mengabaikan prinsip kesetaraan. Hal ini dapat terlihat dari materi penerimaan dana kampanye yang setengah-setengah dibatasi, pengeluaran dana kampanye yang sama sekali tidak diatur, mekanisme pelaporan dana kampanye yang kurang mendetail dan membingungkan hingga isu krusial penegakan hukum yang patut menjadi pertanyaan terkait dengan sanksisanksi hukum yang tidak menyeluruh memayungi aturan dana kampanye. (2) Banyaknya celah yang ada dalam aturan dana kampanye yang tercantum dalam UU No 8 Tahun 2012 memberikan implikasi negatif dimana calon legislatif yang mempunyai kekuatan finansial melimpah 
dapat mereduksi potensi calon lain yang tidak memiliki daya saing ekonomi. Hal ini seakan akan peserta pemilu memiliki kebebasan tak terkontrol dalam menghambur-hamburkan uang pada proses kampanye. sementara kebenaran pelaporan dana kampanye menjadi tanda tanya besar karena tidak menyeluruh dan terbatas menimbulkan resiko tinggi peserta menjadi tidak taat untuk melakukan tindakan-tindakan menyimpang.

Penelitian selanjutnya oleh Saiful Lizam (2016) dengan judul "Pengelolaan Dana Kampanye Partai Demokrasi Indonesia Perjuangan Kota Tanjungpinang Pada Pemilu Legislatif Tahun 2014", penelitian ini menggunakan analisis deskriptif kualitatif. Dari hasil penelitian bahwa pengelolaan dana kampanye PDIP telah mengikuti prosedur yang diatur dan diamanatkan Undang-undang dan Peraturan Komisi Pemilihan Umum. Akan tetapi dalam laporan keuangan yang diperiksa oleh lembaga audit independent yang ditunjuk langsung oleh KPU kota Tanjungpinang terdapat beberapa pelanggaran mulai dari terlambatnya penyerahan laporan keuangan partai yang melebihi dari batas waktu yang diberikan oleh KPU, selain itu PDIP hanya melakukan pencatatan pada penerimaan dana saja namun pada pengeluarannya hanya mencantumkan dana biaya rapat umum saja. Selain itu terdapat ketidaksesuaikan data antara hasil wawancara dan laporan yang diserahkan PDIP kepada KPU. Berdasarkan LPPDK, PDIP hanya menerima sumbangan dari calon legislatif, namun dari hasil wawancara di nyatakan bahwa PDIP menerima sumbangan bukan hanya dari calon tetapi dari perorangan dan juga instansi tertentu akan tetapi responden tidak mau memberitahu secara detail. Hasil penelitian ini dapat di simpulkan bahwa laporan dana kampanye PDIP secara prosedural telah mengikuti kaidah akan tetapi belum di temui aspek transparansi dan akuntabel baik dari sisi pendapatan maupun pengeluaran terlihat dari masih banyaknya perbedaan perbedaan jumlah dana yang ditemui, rincian-rincian yang tidak transparan, serta daftar-daftar penyumbang yang dirahasiakan.

Penelitian ketiga oleh Iwan Sugiwa (2015) dengan judul "Analisa Tingkat Kepatuhan Pelaporan Dana Kampanye Partai Politik Peserta Pemilu Berdasarkan Hasil Audit Laporan Dana Kampanye Di Provinsi Bali Pada Pemilu Legislatif 2014", penelitiannya menggunakan pendekatan kuantitatif berjenis deskriptif dan didukung dengan pendekatan kualitatif berjenis deskriptif. Hasil dari penelitian yang dilakukan oleh Iwan Sugiwa menyimpulkan bahwa : (1) bahwa dari 25 partai politik yang dijadikan sampel penelitian diketahui bahwa 92\% mematuhi unsur kepatuhan ketepatan waktu pelaporan, (2) dari 25 partai politik yang dijadikan sampel penelitian diketahui bahwa 92\% memenuhi unsur kepatuhan pelaporan sumbangan dana kampanye, (3) untuk partai politik di provinsi Bali, secara keseluruhan mematuhi seluruh aturan mengenai pelaporan dana kampanye. Hanya ada 1 partai di tingkat provinsi yang tidak melaporkan dana kampanyenya, yakni Partai Bulan Bintang (PBB). Namun, dikarenakan partai ini tidak mendapatkan suara terbanyak, maka sanksi pembatalan suara tidak bisa dikenakan partai ini tidak memenangi pemilu atau tidak mendapatkan suara terbanyak dalam pemilu legislatif tahun 2014 di Provinsi Bali.

\section{PEMBAHASAN}

Istilah Keuangan Politik didefinisikan sebagai penggunaan uang atau penggunaan materi lain sebagai sumber daya untuk kegiatan politik. Termasuk sumber maupun sarana dalam kegiatan politik yang di biayai pemerintahan tertentu. Secara umum konsep keuangan politik memiliki dua arti yaitu pertama, uang yang di gunakan untuk keperluan 
pemilu (dana kampanye) dan kedua, uang yang dan digunakan untuk pengeluaran Parpol (dana partai). (Eme \& Anyadike, 2014)

Sedangkan menurut (IDEA, 2016), keuangan politik secara umum merujuk pada semua uang yang berperan dalam proses politik. Oleh sebab itu keuangan politik di definisikan sebagai aktivitas keuangan baik sumber yang sesuai hukum ataupun melanggar hukum dan di pergunakan untuk membiayai aktivitas Parpol atau kampanye pemilu (kampanye oleh oleh kandidat termasuk kampanye oleh pihak ketiga).

Parpol sendiri menjadi bagian integral dalam tata kelola keuangan, seperti pengelolaan sumber pendanaan atau pendapatan operasional organisasi partai, serta belanja ataupun pengeluaran yang harus dilakukan untuk menjaga keberlanjutan dan kinerja organisasi. (Manar, 2016)

Setidaknya terdapat tiga sumber alternatif dalam pendanaan parpol, yaitu pertama, iuran anggota Parpol, kontribusi para Kader Parpol, atau unit bisnis yang di dirikan dan di kuasai oleh Parpol. Kedua, dari sektor swasta yaitu (unit bisnis swasta, organisasi dan kelompok masyarakat, dan kontribusi individu,). Ketiga, dari bantuan keuangan negara (APBN atau APBD). (Manurung, 2015)

Masing-masing sumber pendanaan ini memiliki implikasi keuangan yang berbeda yang memerlukan pendekatan berbeda terkait mekanisme akuisisi, kontrol, dan pelaporan. Sumbangan pihak ketiga misalnya, memerlukan kapasitas pengumpulan dana yang memenuhi syarat, sementara iuran keanggotaan memerlukan pembentukan organisasi di akar rumput yang dapat meningkatkan keterlibatan masyarakat. Dana bantuan negara tidak memerlukan upaya untuk pengumpulan dana. Mekanisme kontrol ini memerlukan pendekatan yang berbeda. Bantuan negara umumnya lebih mudah untuk dipantau karena mereka diberikan dalam jumlah besar. iuran keanggotaan memiliki potensi untuk disalahgunakan jika mereka tidak terkontrol dengan baik. Akan tetapi, tantangan terbesar pada pemantauan dan pengawasan justru pada sumbangan yang di berikan pihak ketiga terutama jika jumlahnya sangat besar. Selain indikasi penyalahgunaan, sumbangan pihak ketiga juga cenderung di rahasiakan dan di samarkan dalam pembiayaan kampanye politik masing-masing anggota partai. (IDEA, 2016)

Terdapat beberapa Indikator dalam laporan keuangan politik sehingga dapat di katakan transparan dan akuntabel. Minimal, laporan keuangan politik harus: Komprehensif dan mengidentifikasi pemasukan, pengeluaran, hutang dan aset. Sifat dan keseluruhan kontribusi harus spesifikasi dan pendonor harus teridentifikasi. Tepat waktu. Laporan harus terus berlanjut dan berkesinambungan melalui siklus pemilu, akan tetapi jika bertujuan memberikan informasi terhadap pemilih (konstituen) atas biaya-biaya "costs" kampanye, maka laporan harus tersaji bahkan jauh hari sebelum hari pemungutan suara serta mudah di akses oleh publik serta adanya sanksi ketat atas laporan yang tidak sesuai, tidak lengkap atau tidak tepat waktu (IDEA, 2012).

Dana Kampanye menjadi bagian tak terpisahkan dari keuangan Parpol, dimana dana kampanye merupakan kelanjutan dari aktivitas Parpol pada masa pemilu dengan tujuan mempengaruhi pemilih selama masa pemilu. (Pinilih, 2017:76). Lawrend Shepard dalam (Anjalline, Anggraini, \& Indrayati, 2014, p. 46) mengatakan "Perilaku pemilih banyak di pengaruhi oleh incumbent dan opini publik, namun kontestasi dan pembelanjaan kampanye juga mempengaruhi tingkat partisipasi." Secara tidak langsung pendanaan kampanye akan mempengaruhi partisipasi dalam pemilu, untuk itu perlu adanya pengaturan dana 
kampanye sehingga sesuai dengan asas keadilan.

Menurut (Minan, 2012) setidaknya ada dua prinsip yang mendasari pengaturan dana kampanye pemilu yaitu keterbukaan "transparency" dan keadilan "fairness". Kedua prinsip tersebut memiliki orientasi tujuan dan hasil yang berbeda. Dimana prinsip keterbukaan lebih di tekankan untuk membangun keterbukaan keuangan partai politik. Sedangkan tujuan dari prinsip keadilan yaitu untuk mendorong pada kemampuan Parpol dalam pencapaian kesetaraan akses (memperoleh pendanaan) serta kemampuan dalam pembiayaan kampanye.

Guna terjaminnya sumber pendanaan kampanye yang transparan dan akuntabel, maka dana kampanye perlu di atur sehingga terhindar dari penyalahgunaan dan berbagai penyimpangan penyimpangan, khususnya pada sumbersumber pendanaan yang di gunakan Pasangan Calon (Paslon) maupun Parpol pengusung.

\section{Pengaturan dan Pelaporan Dana Kampanye}

Menurut PKPU No. 5 Tahun 2017 pasal 1 ayat 9 menyatakan bahwa "dana kampanye adalah sejumlah biaya berupa uang, barang dan jasa yang digunakan Pasangan Calon dan/atau Partai Politik atau Gabungan Partai Politik yang mengusulkan Pasangan Calon untuk membiayai kegiatan Kampanye Pemilihan". Pengaturan dana kampanye bertujuan untuk: Pertama, memastikan terwujudnya kontestasi yang adil dan sehat. Kedua, mencegah munculnya pertimbangan pragmatisme pemilih dalam memutuskan pilihan. Ketiga, memastikan kesempatan yang sama bagi peserta pemilu untuk bertarung dan kesempatan yang lebih luas bagi pemilih untuk melihat opsi yang berbeda dalam pemilu. Keempat, mencegah agar kebijakan yang di buat oleh pejabat terpilih tidak di kendalikan oleh penyumbang kampanye. Kelima, menjamin calon yang baik (meskipun tidak memiliki banyak uang tetapi dapat terpilih) dalam pemilu (minan, 2016).

Pada pilkada serentak tahun 2018, pengaturan dana kampanye diatur melalui Undang-Undang No 10 Tahun 2016 Tentang Pemilihan Kepala Daerah dan Peraturan Komisi Pemilihan Umum No. 5 Tahun 2017 Tentang Dana Kampanye.

Hal-hal pokok yang diatur pada regulasi dana kampanye yaitu a) Pembukaan Rekening Khusus Dana Kampanye, b) Pengaturan Sumber Pendanaan, c) Pembatasan Jumlah Sumbangan, d) Laporan Dana Kampanye, e) Audit Dana Kampanye, f) Penerapan Sanksi Administrasi.

Pembukaan rekening khusus dana kampanye dilakukan untuk mengakomodasi seluruh penerimaan dana kampanye, maka pasangan calon wajib untuk membuka rekening khusus, dimana rekening khusus ini terpisah dari rekening Paslon atau Parpol. Paslon atau Parpol hanya boleh menggunakan 1 (satu) rekening penampung dana kampanye. Jika aturan ini di implementasikan secara konsisten dan benar baik oleh Paslon maupun Parpol, maka tidak akan ada lagi dana-dana illegal yang beredar.

Sumber pendanaan merupakan hal yang vital, sehingga perlu Pengaturan Sumber Pendanaan. Dalam pemilu, uang bisa di ibaratkan bahan bakar dari mesin partai dan tim sukses. Hal paling esensial dalam dana kampanye adalah asal muasal dari sumber dana tersebut. Pasalnya, hitam-putih pemimpin yang terpilih sangat ditentukan dari sumber dana politik yang di terima dan di pergunakannya. Semakin banyak pejabat terpilih menggunakan dana "haram" dalam kontestasi electoral yang dilaluinya, maka akan semakin tersandera elite tersebut saat berkuasa. Hal ini yang sebaliknya, semakin bersih dana kampanye yang di pergunakannya maka pemerintahan tersebut lepas dari sanderaan pemodal politik. 
Dalam regulasi pilkada, telah diatur sumber-sumber dana kampanye yang sah. Dimana sumber dana tersebut berasal dari: pertama, Parpol atau gabungan Parpol; kedua, sumbangan dari pihak lain yang sah dimata hukum. Secara eksplisit yang di maksud dengan pihak lain adalah perseorangan atau kelompok atau badan hukum swasta. Sumbangan tersebut dapat di berikan dalam 3 (tiga) bentuk yaitu uang, barang, dan jasa.

Sumber yang tidak sah yaitu sumbangan dari: pertama, segala sesuatu yang bersumber negara asing, seperti badan swasta asing, LSM asing maupun dari warga negara asing; kedua, pemberi bantuan ataupun penyumbang tanpa identitas jelas; ketiga, Pemerintah dan Pemerintah Daerah; dan keempat, perusahaan milik negara seperti BUMN, BUMD, dan sebutan lainnya.

Pembatasan jumlah sumbangan, menjadi limitasi yang pada dasarnya di fokuskan kepada dua aspek, yakni membangun kesetaraan dan menghindari konflik kepentingan. Prinsip yang harus di ingat bahwa pemilu yang demokratis harus memastikan kesetaraan setiap peserta untuk bersaing. Salah satu unsur kesetaraan yang seringkali timpang adalah kesetaraan dalam aspek sumber daya yang di miliki oleh peserta pemilu itu sendiri.

Limitasi dana kampanye diatur pada pasal 7 PKPU No. 5 Tahun 2017, dengan rincian sebagai berikut: Pertama, Dari Parpol atau Gabungan Parpol, tidak boleh melebihi Rp. 750.000.000. Kedua, Dari sumbangan pihak lain perseorangan, tidak boleh melebihi Rp. 75.000.000. Ketiga, Dari sumbangan pihak lain kelompok atau badan hukum swasta, tidak boleh melebihi Rp. 750.000.000.

Untuk memastikan sumbangan tidak berasal dari sumber yang tidak jelas, maka para penyumbang wajib menyertakan identitas lengkap seperti identitas Pribadi, Kelompok, Parpol, swasta serta identitas lainnya seperti NPWP, NIK Dan lain-lain lebih rinci dapat dilihat pada pasal 8 PKPU No. 7 Tahun 2017.

Seluruh sumbangan yang masuk bersifat akumulatif, adapun pembatasan jumlah pengeluaran Paslon di sesuaikan dengan kebutuhan dan letak geografis wilayah pemilihan dan di atur melalui pedoman teknis yang di keluarkan oleh KPU Provinsi/Kabupaten/Kota yang melaksanakan pemilihan. Akan tetapi limitasi di atas hanya mengatur batasan sumbangan di luar Paslon, artinya belum ada ketentuan yang mengatur seberapa besar batasan pengeluaran dari paslon itu sendiri.

Laporan Dana Kampanye, sebagai Penggunaan dana publik harus di pertanggungjawabkan melalui suatu laporan keuangan dengan sejumlah kewajiban yang harus dilakukan oleh Paslon, seperti membuka daftar donasi dan identitas donatur serta menyiapkan laporan dana kampanye dengan mencantumkan semua pendapatan dan pengeluaran kampanye. Tujuan membuka daftar donatur dan laporan dana kampanye adalah untuk menguji prinsip akuntabilitas, dengan memastikan tanggung jawab dari Paslon dan Parpol pengusung. Agar dana yang di terima dan di keluarkan sesuai dengan kaidah dan etik hukum yang berlaku.

Prinsip transparansi dan akuntabilitas dalam manajemen dan pengelolaan dana kampanye dapat dibuat dari tiga sisi: pertama, Pendapatan atau Penerimaan, kedua, Belanja atau Pengeluaran, dan ketiga, Pelaporan (Perludem, Siaran Pers, 30 April 2013)

Untuk mempermudah Paslon dalam menyusun pertanggungjawaban dana kampanye, KPU telah membuat formatformat khusus, yang mana format-format tersebut dapat di lihat dalam lampiran PKPU No. 7 Tahun 2017. LADK wajib di laporkan ke KPU paling lambat 1 (satu) hari setelah masa kampanye berakhir. Laporan dana kampanye yang wajib diserahkan Paslon di bagi menjadi 3 
(tiga) laporan yaitu: 1) Laporan Awal Dana Kampanye (LADK) dimana laporan ini wajib di serahkan ke KPU paling lambat 1 (satu) hari sebelum memasuki masa kampanye; 2) Laporan Penerimaan Sumbangan Dana Kampanye (LPSDK), Paslon di larang menerima sumbangan 1 (satu) hari sebelum LPSDK di laporkan ke KPU; 3) Laporan Penerimaan dan Pengeluaran Dana Kampanye (LPPDK).

Laporan dana kampanye dari pasangan calon perlu di lakukan audit, guna memastikan apakah laporan tersebut memenuhi aspek kepatuhan atau tidak yaitu dengan menilai kesesuaian antara laporan yang di serahkan dengan aturan dana kampanye. Inilah yang menjadi bagian dari Audit Dana Kampanye.

KPU Provinsi/Kota/Kabupaten tentu tidak memiliki kapasitas untuk mengaudit laporan dana kampanye, untuk itu KPU Provinsi/Kota/Kabupaten menunjuk Kantor Akuntan Publik (KAP) yang telah memenuhi kualifikasi yang telah di tentukan. Adapun laporan yang di periksa adalah LPPDK. Dalam melakukan audit, KAP di berikan waktu 15 (hari) untuk memeriksa asersi (Asersi adalah pernyataan yang dibuat oleh Pasangan Calon yang digunakan untuk keperluan audit) Paslon dan laporan dana kampanye sejak hari laporan dana kampanye di serahkan oleh KPU Provinsi/Kabupaten/Kota untuk di audit.

Hasil laporan audit dana kampanye kemudian di serahkan kepada Paslon oleh KPU Provinsi/Kabupaten/Kota maksimal 3 (hari) setelah diterima dari KAP. Hasil Audit Dana Kampanye juga kemudian di umumkan di papan pengumuman serta website sebagai bagian dalam keterbukaan informasi publik. Dari sini masyarakat (kostituen) juga bisa menilai transparansi dan akuntabilitas dari Paslon dalam pendanaan kampanye.

Penerapan Sanksi Administrasi adalah untuk menjamin Independensi, Imparsialitas, Profesionalisme melalui peraturan perundang-undangan dan peraturan KPU mengenai dana kampanye telah di atur sanksi dalam upaya mendorong agar Paslon memberikan laporan yang transparan dan akuntabel. Adapun sanksi pelanggaran dalam penggunaan dan pelaporan dana kampanye adalah sebagai berikut: Pertama, Paslon yang dengan sengaja memberikan keterangan yang tidak benar pada laporan dana kampanye; Kedua, perolehan sumbangan yang melebihi batasan tetapi tidak menyetorkan kelebihan sumbangan tersebut kepada negara dan tidak menyampaikannya ke KPU; Ketiga, melanggar ketentuan pembatasan pengeluaran dana kampanye; Keempat, keterlambatan dalam menyampaikan LPPDK ke KPU; Kelima, menggunakan sumber dana yang di larang baik oleh paslon maupun parpol pengusung. Atas pelanggaran tersebut maka paslon dapat di kenakan sanksi berupa diskualifikasi sebagai pasangan calon atau pembatalan sebagai pemenang pemilu.

\section{Celah dan Kelemahan Aturan Dana Kampanye}

Setidaknya terdapat dua celah yang biasa di gunakan oleh Paslon agar dana kampanye yang di gunakan tidak terdeteksi pada laporan dana kampanye. Pertama, sumbangan tanpa melalui rekening khusus dana kampanye. Hal ini di maksudkan agar sumber pendanaan kampanye yang di gunakan tidak terdeteksi, apakah itu berasal dari sumbangan yang di larang maupun sumber dana yang tidak legal. Pada pilkada serentak tahun 2018, Bawaslu menemukan sekitar total Rp. 14 Milyar dana kampanye yang di gunakan oleh Paslon di luar rekening khusus yang telah di laporkan ke KPU, dengan rincian Rp10.805.174.636 di gunakan pada tingkat kabupaten/kota dan Rp3.984.157.334 di gunakan pada tingkat provinsi (cnnindonesia.com, 13/03/2018). Selaras dengan temuan dengan bawaslu, PPATK 
menemukan 143 transaksi mencurigakan dimana 23 transaksi diantaranya terdapat di pilkada jabar tahun 2018 (liputan6.com, 08/06/2018) www.liputan6.com, PPATK Catat 23 Transaksi Mencurigakan Terkait Pilkada Serentak di Jabar, tanggal 08 juni 2018. Di akses tanggal 20 Juni 2018.

Kedua, Sumbangan melalui uang tunai. Menerimaan sumbangan dalam bentuk tunai akan sulit terdeteksi oleh penegak hukum karena tidak tercatat secara resmi pada sistem keuangan. Jika pun ada indikasi penggunaan uang tunai akan sulit dalam menelusuri aliran dana tersebut, baik sumber dana maupun ke absahan uang tersebut, padahal modus seperti ini bisa di kategorikan sebagai tindak pencucian uang. PPATK mencatat sekitar 1.092 laporan transaksi tunai yang mencurigakan pada pilkada serentak 2018 (liputan6.com, 08/06/2018) www.cnnindonesia.com, Bawaslu Temukan Rp14 M di Luar Dana Kampanye Paslon Pilkada, tanggal 13 Maret 2018. Di akses tanggal 20 Juni 2018.

Celah di atas di manfaatkan Paslon untuk mengumpulkan dana sebanyakbanyaknya tanpa perlu mengikuti aturan mengenai pembatasan ataupun sumber yang sah atas pendanaan kampanye, karena dengan menggunakan mekanisme tersebut penerimaan dan pengeluaran dana kampanye tidak akan tercatat pada rekening khusus sehingga paslon tidak perlu bersusah payah untuk mencatat setiap transaksi pada laporan dana kampanye. Celah di atas juga mengindikasikan bahwa masih terdapat kelamahan dalam pengawasan dan sanksi yang di terapkan pada Paslon terkait penggunaan dana kampanye.

Kelemahan lain adalah audit yang di lakukan berdasarkan pada seluruh transaksi keuangan yang tercatat melalui rekening khusus dana kampanye, termasuk sumbangan dalam bentuk uang tunai wajib di setor ke rekening khusus tersebut. Akan tetapi pada praktiknya banyak sekali modus donasi tanpa melalui transaksi bank sehingga hal ini yang tidak terdokumentasi dan tidak terdeteksi.

Menurut (Saputra, 2013) Penggunaan uang tunai dalam transaksi keuangan dari orang perorang secara langsung, otomatis akan memutus hubungan (nexus) antara pelaku kejahatan dengan tindak pidana dan aset kejahatan. Dengan demikian, tujuan menyamarkan atau menghilangkan asal usul harta hasil kejahatan secara sempurna dapat dilakukan.

Banyaknya transaksi-transaksi mencurigakan yang terjadi pada masa kampanye menjadi bukti bukti lemahnya fungsi pengawasan. Dalam konteks pengawasan sendiri Bawaslu hanya memperoleh peran yang sangat sempit dimana dalam PKPU No. 7 Tahun 2017 bawaslu hanya di berikan wewenang untuk memperoleh akses data terhadap laporan dana kampanye bukan pada proses aliran dana masuk dan keluar. Ini jelas pekerjaan rumah untuk bawaslu dan penegak hukum memastikan dana kampanye berasal dari sumber yang legal.

Pembatasan sumbangan dana kampanye menjadi aspek penting membangun kesetaraan sesuai dengan prinsip pemilu yang demokratis dan adil. Langkah pembatasan sumbangan yang di atur melalui regulasi sudah sangat baik akan tetapi masih terdapat kekurangan yaitu belum adanya batasan sumbangan dari kantong pribadi masing-masing Paslon, Paslon berkantong tebal bisa melakukan kampanye lebih massif dan intensif di bandingkan peserta lainnya sehingga prinsip kesetaraan yang coba di bangun menjadi bias.

\section{SIMPULAN}

Pengaturan dana kampanye memberikan keleluasaan pada Paslon untuk mengumpulkan dana kampanye dari sumber-sumber yang sah, pada saat yang sama kemandirian mereka tetap terjaga sehingga terhindar dari adanya politik balas budi dari para penyumbang. Selain itu pengaturan dana kampanya juga 
membangun kesetaraan dalam kontestasi pemilu. Begitu juga dengan adanya laporan penerimaan dan pengeluaran dana kampanye yang wajib di serahkan oleh Paslon serta sanksi administrasi terhadap pelanggar, menjadi instrumen dalam mendorong transparansi dan akuntabilitas penggunaan dana kampanye, serta menjadi bagian dalam pengawasan berupa kepatuhan terhadap aturan dana kampanye, yang tentunya di harapkan akan berdampak positif untuk meningkatkan kepercayaan dari konstituen (para pemilih).

$$
\text { Laporan penerimaan dan }
$$

pengeluaran dana kampanye yang di umumkan melalui papan pengumuman dan website

KPU

Provinsi/Kabupaten/Kota menjadi sarana keterbukaan informasi publik. Hal ini dapat mendorong orang-orang yang berkepentingan termasuk masyarakat pada umumnya untuk ikut berpartisipasi dalam pengawasan dana kampanye serta dapat mendorong Paslon melaporkan dana kampanye yang dapat di pertanggungjawabkan.

\section{DAFTAR PUSTAKA}

Anjalline, I., Anggraini, R. R., \& Indrayati, R. (2014, April). Pengaturan Dana Kampanye Pemilihan Umum Sebagai Tanggung Jawab Calon Anggota Legislatif Berdasarkan Undang Undang Nomor 8 Tahun 2012 Tentang Pemilihan Umum Anggota Dewan Perwakilan Rakyat, Dewan Perwakilan Daerah, Dan Dewan Perwakilan Rakyat Daerah. e-Journal Lentera Hukum, 1(1): 4253.

Arliman, L. (2016). Keterbukaan Keuangan Partai Politik Terhadap Praktik Pencucian Uang. Jurnal Cita Hukum, 4(2): 225-240.

Eme, O., \& Anyadike, N. (2014). Political Financing In Africa: A Comparative Study Of Kenya and Nigeria: Proposal for Reform. Mediterranean Journal of Social Sciences, MCSER Publishing, Rome-Italy, 5(27): 22-34.

IDEA, I. (2012). Pendalaman Demokrasi: Strategi untuk Meningkatkan Integritas Pemilihan Umum di Seluruh Dunia. Stockholm: International IDEA.
(2016). Pendanaan Partai Politik dan Kampanye Pemilu. Stockholm: International IDEA.

Isra, S., Asshiddiqie, J., Surbakti, R., Zuhro, R. S., \& Santosa, T. (2015). Pemilihan Umum Serentak. (K. Fahmi, C. Simabura, \& F. Amsari, Eds.) Jakarta: PT. Raja Grafindo Persada.

Lizam, S. (2016), Pengelolaan Dana Kampanye Partai Demokrasi Indonesia Perjuangan Kota Tanjungpinang Pada Pemilu Legislatif Tahun 2014, Skripsi. Universitas Maritim Raja Ali Haji Tanjungpinang

Manar, D. G. (2016). Akuntabilitas Partai Politik Di Kota Semarang: Kajian Pelaksanaan Akuntabilitas Pada Partai Demokrat Di Kota Semarang Tahun 2009-2014, 2(1): 5-18.

Manurung, T. R. (2015). Perkembangan Politik Hukum Pertanggungjawaban Partai Politik Dalam Pengelolaan Bantuan Keuangan Negara Pasca Reformasi. Yustisia, 4(1): 118128.

Minan, A. (2012). Transparansi dan Akuntabilitas Dana Kampanye Pemilu: Ius Constituendum dalam Mewujudkan Pemilihan Umum Yang Berintegritas. Jurnal Pemilu dan Demokrasi, 3(1): 79-106.

Network, A. E. (2013). The ACE Encyclopaedia: Electoral Integrity. ACE Electoral Knowledge Network.

Pinilih, S. A. (2017). Mendorong Transparansi dan Akuntabilitas Pengaturan Keuangan Partai Politik. Mimbar Hukum, 29(1): 69-81.

Purwoko, B. (2015). Organisasi dan Birokrasi Pemiliu. Yogyakarta: FISILPOL UGM.

Saputra, R. (2013). Mendorong Transparansi Dan Akuntabilitas Dana Kampanye Melalui Pembatasan Transaksi Keuangan Tunai. Jurnal Pemilu dan Demokrasi, 6: 63-86.

Sugiwa, I. (2015). Analisa Tingkat Kepatuhan Pelaporan Dana Kampanye Partai Politik Peserta Pemilu Berdasarkan Hasil Audit Laporan Dana Kampanye Di Provinsi Bali Pada Pemilu Legislatif 2014. Ekonomi Dan Bisnis, 14(1): 35-40.

Supriyanto, D. (2013). Basa-basi Dana Kampanye. Jakarta: Yayasan Perludem. (2015). Dana Kampanye Pilkada. Jakarta: Yayasan Perludem.

Surbakti, R. (2015). Peta Permasalahan dalam keuangan Politik di Indonesia. Jakarta: Kemitraan.

\section{Undang-Undang dan Peraturan KPU}

Undang-Undang No 10 Tahun 2016 Tentang Pemilihan Kepala Daerah.

Undang-Undang No. 7 Tahun 2017 tentang pemilihan umum. 
JPPUMA: Jurnal Ilmu Pemerintahan dan Sosial Politik UMA (Journal of Governance and Political Social UMA), 6 (2) (2018): 112-121.

Peraturan Komisi Pemilihan Umum No. 5 Tahun 2017 Tentang Dana Kampanye.

\section{Internet}

Minan, A. (2016, Desember 2). Strategi Penelurusan Penyumbang Dana Kampanye Dalam Pilkada. Diunduh diwww.slideshare.net/ahsanov/strategipenelusuran-penyumbang-dana-kampanyedalam-pemilukada tanggal 23 Juni 2018.

Perludem. (2013, April 30). Siaran Pers. Diunduh di www.perludem.org/category/siaran-pers/ tanggal 6 Juni 62018.

Indonesia, CNN. (2018, Maret 13). Bawaslu Temukan Rp14 M di Luar Dana Kampanye
Paslon Pilkada. Diunduh di www.cnnindonesia.com/nasional/20180313 070302-32-282494/bawaslu-temukanrp14-m-di-luar-dana-kampanye-paslonpilkada tanggal 13 Maret 2018.

Simbolon, H. (2018, Juni 08). PPATK Catat 23 Transaksi Mencurigakan Terkait Pilkada Serentak di Jabar. Diunduh di www.liputan6.com/pilkada/read/3553358/ ppatk-catat-23-transaksi-mencurigakanterkait-pilkada-serentak-di-jabar tanggal 20 Juni 2018 